\title{
A EMBAIXADA PERMANENTE E AS ORIGENS DA DIPLOMACIA
}

\author{
Vicente Marotta Rangel \\ Professor Titular do Departamento de Direito Internacional da \\ Faculdade de Direito da USP
}

\begin{abstract}
Resumo: $O$ objetivo do artigo é demonstrar que antes da criação das embaixadas permanentes havia freqüentemente na Europa e na Ásia atividades diplomáticas. Precedendo a pesquisa, o Autor preocupa-se em precisar o conceito de diplomacia. Depois, é apresentado o rol dessas atividades.
\end{abstract}

Resumé: Le but de l'article c'est démonstrer qu'avant l'établissement des ambassades permanentes, il y avait souvent en Europe et en Asie des activités diplomatiques. Avant de s'engager dans la recherche, l'Auteur essaie de préciser le concept de diplomatie. Un inventaire de ces activités vient ensuite.

Unitermos: Diplomacia; Imunidade diplomática.

1. É noção difundida, embora nem sempre clarificada e aceita, a de que somente a partir do Século XV se constituíram as chamadas embaixadas permanentes. Discute-se se a prioridade no instituí-las coube à Milão, Veneza ou à Florença, havendo mesmo quem a reivindique para séculos anteriores, ainda que medievais. Cabe-nos, porém, indagar se antes delas teriam havido atos próprios da diplomacia. Existiriam eles? A resposta, afirmativa, promana da leitura de historiadores. Dois textos de Eurípedes Simões de Paula o corroboram. Citemô-los: "Com Justino II (565-578)... os turcos procuram Bizâncio e ofereceram sua aliança contra os persas... Um funcionário bizantino acompanhou os embaixadores até o Khan Dizaboulos..." "Alguns Aspectos das Relações do Ocidente com o Extremo Oriente Durante a Antiguidade e a Idade Média", Revista de História, 1960, no 43, p. 13. Diz ainda o saudoso mestre da Universidade de São Paulo que, "em 568 o grão Khan Dizaboulos envia à Bizâncio uma embaixada para propor uma aliança contra os persas..." "O Comércio de Bizâncio com o Extremo Oriente", Revista Filosofia Ciência e Letras, 1941, p. 63.

2. Todavia não é fácil tarefa precisar as origens da diplomacia. Para o fim de identificá-las, necessário se faz, liminarmente, determinar o próprio conceito de diplomacia, encargo esse, por seu turno, problemático, uma vez que o con- 
ceito se refere a processo inserido na histórid ${ }^{(1)}$. Quanto às definições de diplomacia, convém notar prima facie não corresponderem elas a objetivos isoláveis como os produtos da natureza, que independem das consciências em que os mesmos se apresentam; e nem se inserem entre as definições - como as constantes de leis e regulamentos - que chegam a criar o seu próprio objeto. A definição de diplomacia parece melhor enquadrar-se em uma terceira espécie, a que se refere Jean Baechier ${ }^{(2)}$, a das definiçōes que dependem das consciências humanas e se reportam a fatos inseridos no contexto dos fenômenos sociais, amalgamados entre si de modo a compor uma totalidade orgânica e da qual é praticamente inviável extrair, intacto e delimitado, o objeto a definir.

3. Da variedade de significados do termo "diplomacia" é testemunho a multiplicidade de definiçōes que lhe tem sido propostas. Harold Nicolson se reporta a pelo menos cinco acepçōes: 1) como sinônimo de "política exterior"; 2) como sinônimo de "negociação"; 3) como processo ou mecanismo mediante os quais se leva a cabo essa negociação; 4) como ramo do Serviço Exterior do Estado; 5) como qualidade ou dom abstrato.

que em seu sentido mais favorável implica habilidade na condução da negociação internacional e em seu pior sentido supõe os aspectos mais insidiosos da diplomacia.

Após relatar essas diferentes acepções, propõe-se o autor inglês perfilhar, "como termo de referência", a definição do dicionário de Oxford, a saber: "Diplomacia é o manejo das relações internacionais mediante a negociação; o método mercê do qual se ajustam e manejam essas relações por meio de embaixadores e enviados; o ofício ou arte do diplomático"(3).

4. O termo "diplomacia" remonta etimologicamente, como se sabe, ao termo "diploum", do verbo grego pregar, dobrar, o qual, por sua vez está na origem do vocábulo "diploma", significativo, em Roma, de certas classes de passaportes ou títulos de circulação formados de placa dupla especialmente dobrada ou cozida e, a seguir, por extensão, de documentos de arquivo, relativos a acordos exteriores ou aptos o conferir determinado privilégio a seu titular ${ }^{(4)}$.

(1) Sobre a diferença de abordagem entre a palavra e o conceito no processo da história, vide comentários de Sérgio Buarque de Holanda ao Léxico dos Conceitos Fundamentais de Otto Bruner, Werner Conzt e Reinhart Rosellek: "O Atual e o Inatual na Obra de Leopold von Rank" Revista de História. vol. 100, tomo II, pp. 479-480.

(2) Qu'est-ce que l'idéologie? Paris. Gallimard, 1976, pp. 11/16 (Introduction).

(3) Diplomacy. 3ª ed. London, Oxford University Press, 1963, pp. 13-14.

(4) Rodrigues Araya. "Diplomacia". Enciclopédia Jurídica Omega. Buenos Aires, VIII, p. 890; Chazelle, Jacques. La Diplomatie, 2 ed., Paris, Presses Universitaires de France, 1968, p. 10. 
O mais antigo uso desse termo, com essa acepção, parece remontar, no vocabulário inglês, ao ano de 1645. Leibniz em 1693, e Dumont em 1726, publicaram, respectivamente, o Codex Juris Gentium Diplomaticus e o Corps Universel Diplomatique du Droit des Gens, coletâneas de tratados e demais documentos oficiais. Os termos "diplomaticus" e "diplomatiques", constantes dos títulos dessas obras, eram aplicados - escreveu Satow -

a um corpo ou coleção de papéis governamentais originais,

mas como o assunto dessas coleções particulares era política exterior, corps diplomatique surge como equivalente a

corpo do direito das gentes

e diplomatique como tendo vínculos com relaçōes internacionais. Donde a aplicação do termo às pessoas conectadas com tais assuntos ${ }^{(5)}$. Segundo lembra Jacques Chazelle, o uso de termos "diplomata" e "diplomático", perfilhados na acepção atual a partir do século XVIII, coincide com o processo de acabamento na Europa das primeiras nações modernas ${ }^{(6)}$. Em lugar desses termos, empregavam-se anteriormente - assinala Rodriguez Araya ${ }^{(7)}$ - "negociação" e correlatos.

5. Explica-se a ancianidade das atividades diplomáticas pelo fato de serem elas decorrência do relacionamento entre unidades políticas, o qual é, por sua vez, expressão do impulso natural de sociabilidde. Lembra-se, a propósito, a assertiva de $\operatorname{Redslob}^{(8)}$, segundo a qual

a diplomacia é tão remota quanto os próprios povos.

Sem embargo de eventuais atos de desconfiança e hostilidade, notam-se entre as naçōes mais antigas "certos complexos de interesses recíprocos que pressupōem contato e colaboração entre os indivíduos e as sociedades"... A diplomacia nasceu - observa R. Numelin ${ }^{(9)}$ -

quando pela primeira vez um chefe de tribo enviou junto a outro chefe emissário com o fim de negociar um assunto, ou quando dois chefes de tribos diferentes se reuniram para discutir pacificamente problemas comuns.

(5) Satow, Ernest. A Guide to Diplomatic Practice. 4ª ed., London, Longmans, 1958, p. 2.

(6) Op. cit., p. 10.

(7) Op. cit., p. 890 .

(8) Histoire des grands principes du Droit des Gens. Paris, 1923, p. 78.

(9) Les Origines de la Diplomatie. Paris, 1945, pp. 83-104. 
É bem de ver que a menção no caso à relação entre as tribos deve ser enfocada na perspectiva dos tempos legendários, numa época em que elas constituíam as únicas unidades políticas, providas conseqüentemente de órgão investido de poder de comando. Precederam assim, no tempo, às pólis das comunidades helênicas.

Do relacionamento de unidades políticas, deflui a tendência delas de acomodar seus interesses específicos, eventualmente conflitantes. A idéia de negociação está inserida no conceito de diplomacia. Implícita se encontra ainda nesse conceito a noção de que os contatos entre unidades políticas se processam em atmosfera de paz, a de que pelo menos entre elas não haja estado de beligerância.

Também a idéia de imunidade está inserida no mesmo conceito. Desde as épocas mais distantes se estabeleceu o costume de conceder aos negociantes garantias que se negavam aos guerreiros, as necessárias para que eles pudessem cumprir suas missões, em que pese o fato das restrições severas impostas aos estrangeiros $^{(10)}$. O princípio da imunidade diplomática, pondera Nicolson ${ }^{(11)}$, foi o primeiro a ser firmemente estabelecido. Encontra-se entre os aborígenes australianos, nas leis de Manu, inserido também nos poemas homéricos,

onde os arautos eram vistos como dotados de santidade especial outorgada não apenas por Hermes, senão também pelo próprio Zeus.

Os atenienses e espartanos não ignoravam - adverte Graham Stuart ${ }^{(12)}-$ ter violado esse princípio ao assassinarem o emissário persa de Dario. Quando dois nobres espartanos ofereceram sua vida como reparação, Xerxes mostrou seu respeito ao princípio, recusando-lhes o oferecimento.

6. Nos tempos primevos, a diplomacia se apresentou com três características: ser ambulante, ser inorganizada e estar circunscrita no tempo e no espaço. Este último traço decorria das limitações dos meios de comunicação. Ambulante, ela consistia no envio de negociadores com vistas ao exame de questão precisa: acordos comerciais, tratados de paz, de aliança, solução de litígios e de conflitos armados. Inorganizada, ela vingava de modo rudimentar nas nações mais antigas - egípcios, assírios, judeus, persas - alcançando alguma consistência entre os gregos e, mais ainda, entre os romanos ${ }^{(13)}$

(10) NICOLSon, op. cit., p. 16-17.

(11) The Revolution of Diplomacy. 2ª ed., New York, Collier Books, 1966, p. 11.

(12) Le Droit et la Pratique Diplomatique et Consulaires. Recueil des Cours. Académie de Droit International, 1934-II, t. 48, p. 464.

(13) Cahier, op. cit., p. 22. 
Da ancianidade da diplomacia é prova o tratado de paz assinado por Ramsés II em 1280 a.C., pelo qual se assegurava ao Egito e aos hititas, uma aliança defensiva e ofensiva e mesmo a extradição dos refugiados políticos.

Inexistia na Idade Antiga, lembra Vaughan Williams ${ }^{(14)}$, nada que se assemelhasse a um Ministério de Relações Exteriores.

Em Atenas, por exemplo, a "Ecclesia” geriu os negócios estrangeiros, assim como os internos. Ela recebia os representantes dos Estados estrangeiros e era autoridade que concluía os tratados. Nomeava os funcionários que deveriam participar das diversas missões enviadas para o exterior, os quais, ao regressar, lhe faziam relatório sobre a missão desempenhada (pois raro era confiar a um só homem tal encargo).

Desde o século VI a.C., adotaram as pólis gregas o costume de escolher como embaixadores

os oradores mais eloqüentes, os advogados forenses mais hábeis da comunidade.

Eram designados para defender

a causa de sua cidade perante as assembléias formulares das confederações, ou meramente as unidades estrangeiras.

Não se lhes exigia se informassem dos países visitados ou apresentassem relatório ao regressar, embora pudessem fazê-lo.

Tudo o que se lhes pedia era pronunciarem magnífico discurso.

Foi o que fizeram, no século posterior, os embaixadores atenienses perante a conferência convocada por Esparta em 432 a.C. e que decidiu, não obstante, em prol da declaração de guerra contra Atenas ${ }^{(15)}$. Tais funçōes apenas em parte poderiam, em verdade, ser qualificadas como de diplomáticas, porquanto, além de esporádicas e circunscritas no tempo ${ }^{(16)}$, não eram adstritas a sigilo e os negociadores não se conformavam senão com as normas de sua própria pólis ${ }^{(17)}$

(14) Les Méthodes du Travail de la Diplomatie. Recueil des Cours. Académie de Droit International, 1924-VII, t. 4, p. 231.

(15) Nicolson, op. cit., pp. 18-19.

(16) “Il negoziatore ellenico dell'alleanza o della pace... ha autorità circoscritta a qual negozio... adepiunta la commissione, torna all'invianto porge il recosonto e con ció termina l'ufficio, simile in questo all'anfizione ed al legato" (Santi Nava. "Diplomazia i Diplomatici", Novissimo Digesto Italiano. V, 1960, p. 653).

(17) Chazelle, op. cit., pp. 12-13. 
Tanto méritos quanto deméritos resultaram do sistema das cidades gregas, no dizer de Nicolson. Os méritos consistiram: a) no reconhecimento de que as relaçōes internacionais deveriam ser governadas por princípios estáveis; b) no desenvolvimento dos mecanismos da negociação; c) na prática da diplomacia aberta. Entre os deméritos constou o malogro em superar o descompasso entre a concepção de uma diplomacia democrática e as imposições de governos despó$\operatorname{ticos}^{(18)}$.

7. Legionários, lavradores e construtores de estradas, não eram os romanos, alega-se, tão bem dotados quanto os gregos, para a teoria e a arte das negociações. Mas além dessa possível carência de dom e vocação, a estrutura da sociedade da época em que Roma progrediu e dominou não foi de molde a estimular o progresso da diplomacia. Roma não admitia nenhuma relação de igualdade com as demais cidades, povos, impérios. Ela entrevia essa relação sob um prisma romanocêntrico, colonialista, administrativo. Somente em suas últimas etapas como Império é que Roma sentiu a necessidade da arte da negociação ou de uma diplomacia idônea ${ }^{(19)}$.

Nomeados pelo Senado, os embaixadores romanos - oratores ou nuntii eram designados para atribuições de curta duração, ad hoc, para as quais tinham instruções mas raramente plenos poderes. Deviam ao regressar dar contas da missão recebida. Eram geralmente de nível senatorial. Quanto aos negociadores estrangeiros, Roma lhes concedia imunidades extensivas aos acompanhantes, dos quais se excetuavam, todavia, os empregados. Mas submetia esses negociadores a um protocolo humilhante.

Em relação a dois pontos, pelo menos, Roma imprimiu progresso à arte $\mathrm{e}$ à prática da diplomacia: ao sustentar estarem as imunidades sujeitas à tutela do jus gentium; e ao defender o princípio do respeito às obrigações assumidas em contratos e tratados: pacta sunt servanda.

Ainda no início do último quartel do século IV d.C., o Império Romano ou o mundo romano - orbis romanus - abrangia toda a Europa a oeste e ao sul do Reno e do Danúbio (inclusive a "Bretanha", atual Inglaterra) assim como o Oriente-Próximo asiático, inclusive o norte da Mesopotâmia (com exceção da Arábia) e toda a África mediterrânea. Havia então, é certo, diferenças profundas entre as duas principais partes do Império (partes orientis e partes occidentis). Naquela, era o grego a língua de alta cultura, havia menor número de pagãos, a filosofia helênica gerou concepção do cristianismo que não alcançava a mesma repercussão na parte ocidental. Nesta, além do latim que prevalecia como língua comum e de instrumento de cultura, a vida urbana e o grande co-

(18) The Evolution of Diplomacy, p. 34.

(19) Nicolson, Diplomacy, pp. 23-24. 
mércio tiveram proporções menos extensas. Malgrado essas diferenças, subsistia a unidade, arrimada em passado e aspiraçōes comuns, na autoridade do direito romano, na convergência do poder político, na interconexão regular das duas partes, que se fazia através do mare nostrum, o Mediterrâneo. Tal unidade cessou, todavia, como se sabe, com as grandes invasōes dos "bárbaros", que se sucederam do último quartel do século IV até o fim do século VI, e cuja principal conseqüência foi a queda do Império no Ocidente, ao final do século V. O propósito de restabelecer essa unidade foi o escopo básico do imperador Justiniano, louvado no mesmo ideal romano tradicional que inspirou sua grande obra legislativa. Não obstante êxitos parciais, tal propósito malogrou definitivamente, como se sabe, no plano militar e político ${ }^{(20)}$.

8. Foi com o declínio do Império Romano que a diplomacia - pondera Chazelle ${ }^{(21)}$ - assumiu a forma de arte política, em conseqüência da necessidade de compor rivalidades e conciliar adversários. Essa arte adquiriu impulso na corte de Bizâncio, onde surgiram os primeiros organismos governamentais encarregados de política exterior, se formaram os primeiros negociantes profissionais e as regras de protocolo e de precedências alcançaram importância desmesurada.

Bizâncio tirava sua força e sua segurança

- esclarece Simões de Paula ${ }^{(22)}$ _

da sua organização administrativa, mas esta era mantida pelo seu comércio. A história bizantina é, em grande parte, a história de sua política financeira e do seu comércio. Constantinopla gozou dessa excepcional situação comercial devido principalmente à sua admirável posição geográfica de cidade edificada num estreito que separa a Ásia da Europa, o Oriente do Ocidente, servindo, portanto, de local ideal de reunião a todos os mercadores do mundo. A sua população era composta principalmente de gregos e armênios, dois povos que possuem grande aptidão para o comércio. Nessas condiçōes, não é de admirar que o nome de Bizâncio tenha sido, durante séculos, sinônimo de riqueza, de cidade cujo "tesouro não tem fím nem medida, de cidade dum luxo estranho e magnífico, cujo imperador enviava às Igrejas e cortes bárbaras do Ocidente joias e pedras preciosas.

Não foi sem sólidos motivos, pois, que os turcos enviaram, em 568 , embaixada

(20) Cf. François L. Ganshof, Le Moyen Âge, Histoire des Relations Internationales, I, Paris, Hachette, 1953, pp. 5-11.

(21) Op. cit., p. 14.

(22) “O Comércio de Bizâncio com o Extremo Oriente”, op. cit., pp. 53-54. 
à Constantinopla para propor aliança contra os persas, tanto mais que estes eram

o maior inimigo de Roma no Oriente: rivalidade política, por causa da hegemonia sobre a Armênia, cristalizada no século III, hostilidade religiosa, uma vez que a Pérsia cultuava o masdeísmo, de caráter dualista ${ }^{(23)}$.

Mas não apenas em receber, senão em enviar negociadores, se esmerou o Império bizantino, consciente de que o recurso à diplomacia e não às armas era o melhor instrumento para enfrentar eventuais ameaças de vizinhos poderosos, ou para exercer hegemonia sobre povos mais débeis. Criou-se, no decorrer do século XIII, departamento governamental para assuntos exteriores, que se encarregava de ensinar a arte da negociação e da organização e envio de embaixadas. Outro departamento foi também instituído - Skrinion Barbarón - destinado à recepção e controle das embaixadas estrangeiras. Questões de protocolo e cerimonial suscitavam interesse e sobre elas o Imperador Constantino Porphirogenitus escreveu extenso tratado, que serviu de manual para seus sucessores $^{(24)}$.

Durante algum tempo, o papa manteve representantes permanentes perante o imperador bizantino, os apocrisiários, mas, a partir da primeira metade do século VIII, preferiu ter emissários ad hoc, os missi, ou legati apostolicae sedis. Tanto aqueles, quanto estes, possuíam competência em matéria religiosa, o que tornava difícil assimilá-los aos diplomáticos. Em nível estritamente político e também comercial se mantinham os vínculos entre Constantinopla e cidades italianas, sujeitos, aliás, a diferentes graus de intensidade, a vicissitudes de comunicação e entendimento.

A principal herdeira da experiência e das tradições bizantinas sobre diplomacia foi Veneza,

"velha cidade perdida no fundo do Adriático e assentada sobre um grande número de ilhas na foz do Rio Pó, que conseguira manter-se mais ou menos imune às invasões bárbaras",(25).

(23) Ganshof, op. cit., p. 7.

(24) Cf. J osé Júlio Santa Pinter, Teoría y Práctica de la Diplomacia. Buenos Aires, Depalma, 1958, pp. 37-47. Harold Nicolson, The Evolution of Diplomacy. New York Collier Books, 1966, pp. 39-42. Ganshof, op. cit., pp. 3 8-39. Luis Garcia Arias, Estudios de Historia y Doctrina del Derecho International. Madri, Instituto de Estudios Políticos, 1946, pp. 410-412.

(25) Eurípedes Simões de Paula, Alguns Aspectos da Economia Medieval do Ocidente. Revista de História, 1964, vol. XXIX, p. 281. 
Herdeira também por vocação própria. Sabe-se que, desde o século IX, se distinguira na conservação metódica dos arquivos sobre política exterior, inclusive das instruçōes aos embaixadores e relatórios destes sobre a missão recebida. Tanto o progresso nas relaçōes recíprocas entre as repúblicas italianas, quanto a intensificação dos vínculos que as ligavam a países estranhos à península, concorreram para que as missões diplomáticas usufruíssem, desde o século XIII, de relativa estabilidade e alcançassem uma certa duração, inicialmente, de três a quatro meses e, a partir do século XV, alguns anos ${ }^{(26)}$. Não foi apenas, todavia, o atributo de maior continuidade temporal o critério básico para a qualificação das chamadas embaixadas permanentes, mas também o fato de haver relação de reciprocidade entre os países por ela envolvidos. Mais ainda: as atividades dessas embaixadas não mais se restringiram às tradicionais, de representar e negociar, e passaram a se reportar especificamente às de informar e avaliar com fidelidade e constância.

São Paulo, julho de 1988.

(26) Chazelle, op. cit., p. 15. 